\title{
UTILIZING PLASTIC BOTTLE WASTE WITH THE RE-USE METHOD
}

\author{
Yeti SUKARSIH'1 , Sunu Dwi ANTORO², TRIYONO ${ }^{3}$, Siti ZUHRIYAH ${ }^{4}$, Kus Anjar SISWATI5 \\ 1,2,3,4 Faculty of Teacher Training and Education \\ Universitas Terbuka \\ Email: yeti@ecampus.ut.ac.id
}

\begin{abstract}
This public service program aims to improve the creativity of the community through the re-use of household waste. Not only exciting, this activity may also generate extra income for the community members. The method consists of understanding the issues of environmental health, identifying and determining inorganic waste, and improving creativity through workshops on utilizing inorganic waste to generate side income. The object of this program is the housewives at Dusun Mrisen, Sardonoharjo, Ngaklik, Sleman, Yogyakarta. The activity methods used in this program are lectures, demonstration, and practicum. This public service program is expected to contribute in the improvement of the community's welfare.
\end{abstract}

Key Words: re-use, creativity, side income

\section{PENDAHULUAN}

Kebersihan lingkungan merupakan salah satu program yang memerlukan pengelolaan dengan melibatkan masyarakat mulai kelompok masyarakat yang paling kecil yaitu keluarga. Salah satu faktor penting yang menjadi penyebab utama lingkungan yang tidak bersih, tidak sehat dan tidak nyaman adalah sampah. Keberadaan sampah yang bersumber dari rumah tangga apabila tidak dikelola dengan baik maka lingkungan keluarga dan masyarakat akan terganggu karena akan menciptakan lingkungan yang tidak sehat dan tentu akan berdampak tidak baik. Marliani (2014) menyatakan bahwa dampak negatif yang dapat ditimbulkan oleh volume sampah yang tidak dikelola dengan baik adalah gangguan kesehatan, menurunkan kualitas lingkungan, menurunkan estetika lingkungan dan terhambatnya pembangunan negara Aspek negatif sering tidak disadari oleh masyarakat karena pemahaman tentang sampah dan bagaimana pengelolaannya masih belum mendapat perhatian yang serius. 
Pengelolaan sampah anorganik yang selama ini dilakukan masih menggunakan metode berbeda-beda. Sebagian warga mengelola sampah anorganik dengan cara dijual, ada yang dengan cara membuang bercampur dengan sampah organik, ada juga yang dibakar, dan ada yang ditanam. Penduduk Dusun Mrisen yang memiliki lahan yang agak luas membuang sampah dilakukan dengan membakar atau kadang-kadang dikubur. Sebagian warga sekedar membuang sampah begitu saja. Mereka yang tidak memiliki lahan sisa maka pembuangan limbah rumah tangga diambil oleh orang yang membantu membuang sampah rumah tangga. Pengelolaan sampah rumah tangga yang seperti ini masih menunjukkan pengelolaan yang sudah umum dilakukan orang dan kerugiannya dapat menyebabkan kondisi lingkungan menjadi tidak sehat dan tidak tertata dengan baik. Pengelolaan sampah yang tidak dilakukan dengan cara yang berbasis kebersihan dan kesehatan lingkungan dapat berakibat pada kesehatan dan mengganggu kelestarian lingkungan yang dapat menyebabkan "gangguan fungsi lingkungam pemukiman, hutan, persawahan, sungai dan lautan" (Mariani,2014). Kondisi macam-macam cara pengelolaan sampah anorganik tersebut terjadi karena di Dusun Mrisen memang belum ada keseragaman dalam pengelolaan limbah rumah tangga anorganik yang lebih sehat dan bermanfaat bagi kehidupan sehari-hari.

Kegiatan mengelola sampah rumah tangga yang dilakukan oleh penduduk dusun Mrisen menunjukkan bahwa masyarakatnya masih beranggapan bahwa untuk menjaga kebersihan maka semua sampah harus dibuang, dibakar, dikubur dalam tanah atau dibuang saja. Sampah sebenarnya memiliki manfaat jika dikelola dengan baik di samping berdampak terhadap kebersihan lingkungan dan juga dapat memiliki nilai ekonomis bagi keluarga (Sidarto, 2010). Kesadaran akan sisi positif pengelolaan sampah bagi warga Mrisen belum ada. Dengan perilaku yang demikian pengelolaan sampah di dusun Mrisen tidak dapat dikatakan sebagai pengelolaan sampah karena hanya bersifat alami, atau turun temurun dan memiliki anggapan bahwa sampah itu merupakan kotoran maka masyarakat berpikiran harus dibuang. Pemikiran seperti inilah yang memiliki potensi untuk ditingkatkan pada kesadaran hidup berwawasan lingkungan, sehingga pendidikan lingkungan bagi masyarakat berpeluang untuk dilakukan.

Berdasarkan paparan analisis situasi kondisi masyarakat dusun Mrisen dan perilaku masyarakatnya dalam penanganan sampah; dapat disimpulkan bahwa pengelolaan sampah di dusun Mrisen masih bersifat tradisi, yaitu bersifat turun temurun dan masih bersifat umum. Hal ini disebabkan sebagian besar masyarakatnya belum sepenuhnya memiliki pemahaman tentang sampah, pengelolaan sampah rumah tangga belum dipahami dengan baik, belum memahami pengelolaan sampah dari segi jenisnya maupun cara pengelolaannya. Disamping itu pengelolaan sampah yang bersifat menguntungkan baik dari segi kebersihan lingkungan maupun dari segi keekonomian rumah tangga juga belum dilakukan.

Pengelolaan sampah di dusun Mrisen masih memerlukan pembenahan di hampir semua aspek. Proses ini memerlukan waktu yang lama sehingga jika dilakukan pengelolaan dari awal aspek penyadaran pentingnya pengelolaan sampah membutuhkan waktu. Permasalahan penanganan sampah yang tidak terlalu makan waktu lama adalah pemanfaatan limbah untuk dibuat produk baru yang lebih bermanfaat. Untuk kegiatan penyadaran pentingnya pemanfaatan limbah untuk fungsi lain diperlukan pelatihan dengan menggunakan salah satu contoh. Dalam kasus di dusun Mrisen ini pemanfaatan botol plastik untuk diubah menjadi produk lain yang 
bermanfaat. Dengan melatih membuat aneka produk dari limbah botol plastik ini akan menjadi dasar kreativitas masyarakat untuk berpikir kreatif menggunakan limbah untuk kebutuhan lain. Dan jika ini dikelola dengan baik akan menghasilkan pendapatan tambahan. Sejalan dengan hasil penelitian yang dilakukan oleh Sidarto ( 2010) dalam penelitiannya telah menemukan bukti bahwa pengelolaan sampah rumah tangga terbukti merupakan peluang usaha yang menguntungkan dan sekaligus meningkatkan kebersihan lingkungan.

Dengan memiliki keterampilan daur ulang sampah anorganik masyarakat dusun Mrisen akan memiliki kesadaran pentingnya lingkungan yang bersih dan sehat serta dengan mengelola sampah yang benar justru dapat meningkatkan kemampuan berkreasi warga dalam memanfaatkan limbah. Sehingga secara rinci solusi yang akan dilakukan adalah:

1) Penanaman kesadaran pentingnya kesehatan lingkungan melalui kreatifitas Re-use

2) Kemampuan kreatifitas masyarakat dusun Mrisen mengubah barang bekas menjadi barang berguna/berfungsi lain

3) Kemampuan masyarakat dusun Mrisen dalam pengelolaan sampah anorganik yang bernilai ekonomi

\section{KAJIAN TEORI}

Salah satu permasalahan yang pada umumnya dihadapi masyarakat dalam menjaga kesehatan lingkungan adalah tentang limbah rumah tangga. Setiap hari limbah rumah tangga ditemukan dan harus dijauhkan dari rumah. Demikian juga yang terjadi di Dusun Mrisen.

Cara-cara pengelolaaan tradisional dalam mengelola limbah rumah tangga adalah dengan cara di bakar, di tanam di tanah, dan dibuang di kebun atau sawah. Di samping itu ada beberapa warga yang mempercayakan salah satu orang petugas mengumpulkan sampah untuk dibuang ke tempat pembuangan.

Menimbang betapa pentingnya kebersihan lingkungan tersebut, maka perlu dilakukan sosialisasi kebersihan lingkungan melalui salah satu cara penanganan sampah dengan sitem daur ulang sehingga akan memberikan pendidikan lingkungan keluarga dan masyarakat yang pada akhirnya akan tercapai sebuah pedusunan yang memiliki lingkungan yang bersih dan menambah pengetahuan dan kreativitas pemanfaatan sampah untuk barang lain yang berguna dan dampak positifnya adalah meningkatkan kebersihan lingkungan dan kesehatan. Mengingat wilayah dusun Mrisen yang penanganan sampah organik lebih mudah misalnya dengan menjadikan pupuk tanaman. Oleh karena itu konsentrasi penanganan sampah adalah pada penangan sampah anorganik melalui sistem daur ulang menjadi barang yang lebih bermanfaat. Marliani (2014) menggolongkan salah satu pemanfaatan sampah anorganik kedalam istilah Re-use, yang memiliki makna sebisa mungkin pilihlah barang-barang yang bisa dipakai kembali. Hindari pemakaian barang-barang yang disposable (sekali pakai, buang). Hal ini dapat memperpanjang waktu pemakaian barang sebelum ia menjadi sampah.

Re-use sampah anorganik dalam kegiatan abdimas ini menjadi pijakan awal dalam kegiatan menyadarkan kebersihan lingkungan melalui kreativitas memanfaatkan sampah anorganik menjadi barang yang lebih bermanfaat. Keterpahaman ibu rumah tangga dalam mengelola 
sampah akan sangat efektif dalam menciptakan kebersihan dan kelestarian lingkungan. Seperti yang dikatakan oleh Chaesfa \& Pandjaitan, (2013) "Rumah tangga sebagai unit terkecil dari masyarakat merupakan tempat yang efektif untuk membangun kesadaran lingkungan."

Pemanfaatan botol plastik dalam konsep Re-use dapat dilakukan dengan cara menggunakan kembali menjadi barang dengan fungsi yang berbeda. Misalnya botol air mineral dapat digunakan secara kreasi menjadi tempat pensil, tempat abu rokok dan sebagainya. Plastik bekas makanan anak-anak seperti chitos, chiki dapat dimanfaatkan untuk membuat polibag.

Kemudian yang dipadukan adalah mencakup bagaimana mengelola sampah mulai dari arti kebersihan lingkungan, mengenal sampah rumah tangga dan jenis-jenisnya, serta bagaimana penanganan setiap jenis sampah tersebut. Sehingga jika dalam satu rumah tangga menjaga kebersihan lingkungan dengan cara mendaur ulang sampah anorganik maka akan dicapai lingkungan keluarga yang bersih dan bernilai keekonomian rumah tangga.

Sesuai dengan konsep daur ulang maka solusi yang ditawarkan adalah mencakup :

1) Pemahaman tentang sampah anorganik

2) Penggolongan sampah anorganik

3) Penentuan sampah anorganik untuk Re-use

4) Pengelolaan sampah dengan konsep Re-use

Masyarakat harus paham betul jenis-jenis sampah rumah tangga sehingga akan memudahkan cara mengelolanya. Ada dua jenis sampah rumah tangga yaitu sampah organik dan sampah anorganik. Sampah organik adalah sampah yang dihasilkan dari kegiatan rumah tangga berupa sisa makanan, sayuran, kulit buah, bungkus makan dari daun-daunan. Sedangkan sampah anorganik adalah sampah yang tidak bisa membusuk. Menurut Marliani (2014) yang dimaksud dengan sampah anorganik ialah "sampah yang dihasilkan dari bahan-bahan non hayati baik berupa produk sintetik maupun hasil prosses teknology pengelolahan bahan tambang atau sumber daya alam dan tidak dapat diuraikan oleh alam". Limbah rumah tangga berupa barang yang terbuat dari plastik, kayu, kaca semuanya tidak mudah busuk. Plastik yang dibakar akan menimbulkan bau tidak sedap dan akan mengganggu polusi udara. Oleh karena itu, kondisi penanganan sampah rumah tangga yang masih tradisional maupun masih bersifat turun temurun memerlukan upaya peningkatan pola pikir dan kemampuan pengelolaan sampah.

Program Pengabdian Kepada Masyarakat ini dilaksanakan dengan metode pelatihan, yaitu melalui pelatihan instruksional melalui tahapan-tahapan yang terencana. Meskipun demikian, kombinasi dengan aspek kreativitas membuat pelatihan instruksional ini terbuka dalam hasil akhir. Modul diberikan untuk memberikan pedoman dalam pembuatan pengolahan limbah botol plastik ini. Peserta pelatihan mempunyai pilihan untuk mengikuti modul yang sudah diberikan, atau mengikuti modul dasar dengan menambah elemen lain, ataupun dengan membuat bentuk dasar lain selain modul. Instruksi pada pelatihan diberikan secara verbal oleh tim instruktur kepada peserta pelatihan, bersamaan dengan memberi contoh proses yang langsung diikuti oleh peserta pelatihan. Pada proses kerja tersebut, pembagian waktu yang direncanakan dilakukan secara fleksibel sesuai dengan kemampuan kerja peserta pelatihan. Proses pelatihan tersebut dipaparkan secara deskriptif kualitatif pada makalah ini, untuk memberikan gambaran secara lengkap jalannya 
proses pelatihan dan pembuatan produk pemanfaatan limbah botol plastik menjadi produk rumah tangga.

Upaya peningkatan keterampilan ibu rumah tangga di dusun Mrisen melalui pelatihan pemanfaatan botol plastik menjadi barang alih fungsi dapat digambarkan pada gambar tentang Skema pemanfaatan sampah daur ulang barang bekas:

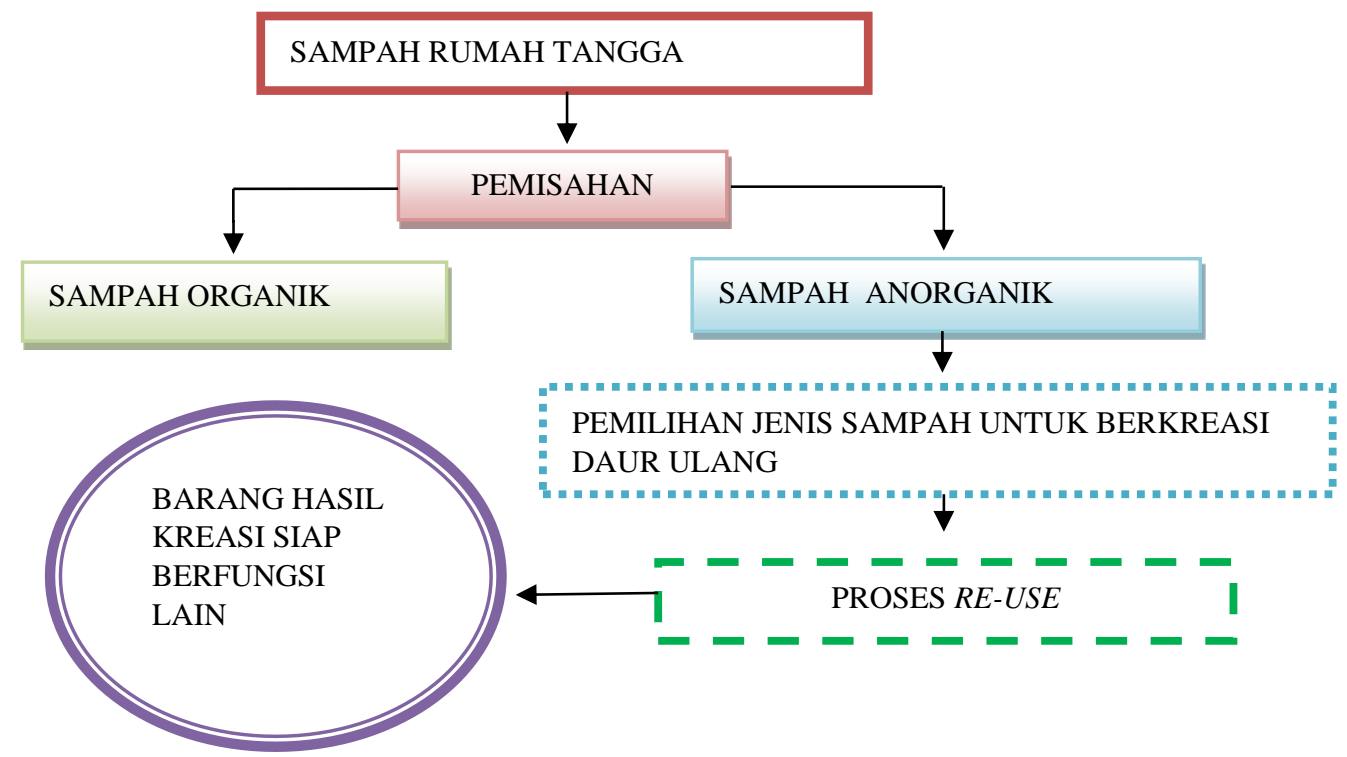

Gambar 1: Skema alur konsep pelatihan pemanfaatan botol plasti untuk alih fungsi

Materi Pelatihan:

a. Pelatihan pembuatan sower, tempat pensil dan tempat lilin

b. Pelatihan pembuatan celengan bentuk kura-kura dan gelas cantik

c. Pelatihan pembuatan tempat assesoris dan tempat pensil rit dan kancing

d. Pelatihan pembuatan tempat sikat gigi unik dan hiasan buah apel

e. Pelatihan pembuatan vas bunga dan tempat sovenir

f. Pelatihan pembuatan toples mini lebaran

\section{METODE PELAKSANAAN}

Berdasarkan informasi dari Kepala Dusun Mrisen, Asih Hadi (2018) dusun Mrisen merupakan salah satu Dusun di wilayah Kelurahan Sardonoharjo, Kecamatan Ngaglik, Kabupaten Sleman Propinsi DIY. Di sebelah utara berbatasan dengan Dusun Kembangan, sebelah Barat berbatasan dengan Dusun Wonosobo, sebelah Timur berbatasan dengan Dusun Turirejo, dan di sebelah Selatan berbatasan dengan Dusun Baturan Mriungan. Dusun Mrisen memiliki luas $85 \mathrm{Ha}$, yang terdiri dari luas pekarangan $12 \mathrm{Ha}$, sedangkan luas sawah $63 \mathrm{Ha}$. Jumlah penduduk Dusun Mrisen adalah 453 kepala keluarga. Yang tergabung dalam 5 RT. Tingkat pendidikan warga dusun Mrisen pada umumnya adalah berpendidikan SLTA. Mata pencaharian yang dominan adalah sebagai buruh dan petani. 
Pelaksanaan kegiatan Pengabdian Kepada Masyarakat ini dilakukan di dusun Mrisen yang merupakan salah satu Dusun di wilayah Kelurahan Sardonoharjo, Kecamatan Ngaglik, Kabupaten Sleman Propinsi DIY. Di sebelah utara berbatasan dengan Dusun Kembangan, sebelah Barat berbatasan dengan Dusun Wonosobo, sebelah Timur berbatasan dengan Dusun Turirejo, dan di sebelah Selatan berbatasan dengan Dusun Baturan Mriungan.
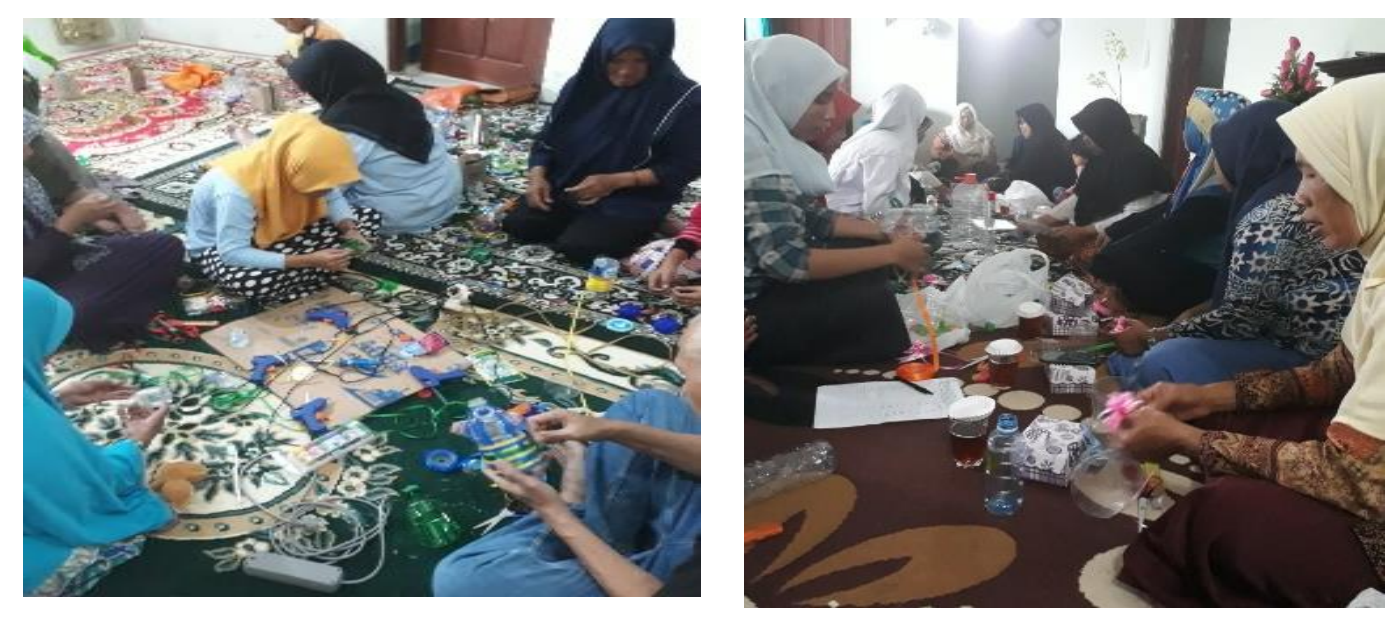

Gambar 2: Tempat pelaksanaan pelatihan

\section{Program Pelatihan}

Menimbang betapa pentingnya kebersihan lingkungan tersebut, maka perlu dilakukan sosialisasi kebersihan lingkungan melalui salah satu cara penanganan sampah dengan sistem daur ulang sehingga akan memberikan pendidikan lingkungan keluarga dan masyarakat yang pada akhirnya akan tercapai sebuah pedusunan yang memiliki lingkungan yang bersih dan menambah pengetahuan dan kreativitas pemanfaatan sampah untuk barang lain yang berguna dan dampak positifnya adalah meningkatkan kebersihan lingkungan dan kesehatan. Oleh karena itu konsentrasi penanganan sampah adalah pada penanganan sampah anorganik melalui sistem daur ulang menjadi barang yang lebih bermanfaat. Marliani (2014) menggolongkan salah satu pemanfaatan sampah anorganik kedalam istilah Re-use, yang memiliki makna sebisa mungkin pilihlah barang-barang yang bisa dipakai kembali. Hindari pemakaian barang-barang yang disposable (sekali pakai, buang). Hal ini dapat memperpanjang waktu pemakaian barang sebelum ia menjadi sampah. 
Re-use sampah anorganik dalam kegiatan abdimas ini menjadi pijakan awal dalam kegiatan menyadarkan kebersihan lingkungan melalui kreativitas memanfaatkan sampah anorganik menjadi barang yang lebih bermanfaat. Keterpahaman ibu rumah tangga dalam mengelola sampah akan sangat efektif dalam menciptakan kebersihan dan kelestarian lingkungan. Seperti yang dikatakan oleh Chaesfa \& Pandjaitan, (2013) "Rumah tangga sebagai unit terkecil dari masyarakat merupakan tempat yang efektif untuk membangun kesadaran lingkungan."

Pemanfaatan botol plastik dalam konsep Re-use dapat dilakukan dengan cara menggunakan kembali menjadi barang dengan fungsi yang berbeda. Fokus pelatihan berkreasi memanfaatkan limbah botol plastik mencakup pelatihan pembuatan sower, tempat pensil dan tempat lilin, celengan bentuk kura-kura dan gelas cantik, tempat assesoris dan tempat pensil rit dan kancing, tempat sikat gigi unik dan hiasan buah apel, vas bunga dan tempat sovenir, dan pelatihan pembuatan toples mini lebaran.

Kemudian yang dipadukan adalah mencakup bagaimana mengelola sampah mulai dari arti kebersihan lingkungan, mengenal sampah rumah tangga dan jenis-jenisnya, serta bagaimana penanganan setiap jenis sampah tersebut. Sehingga jika dalam satu rumah tangga menjaga kebersihan lingkungan dengan cara mendaur ulang sampah anorganik maka akan dicapai lingkungan keluarga yang bersih dan bernilai keekonomian rumah tangga.

Sesuai dengan konsep daur ulang maka solusi yang ditawarkan adalah mencakup :

5) Pemahaman tentang sampah anorganik

6) Penggolongan sampah anorganik

7) Penentuan jenis sampah anorganik untuk Re-use

8) Pengelolaan sampah dengan konsep Re-use

Masyarakat harus paham betul jenis-jenis sampah rumah tangga sehingga akan memudahkan cara mengelolanya. Ada dua jenis sampah rumah tangga yaitu sampah organik dan sampah anorganik. Sampah organik adalah sampah yang dihasilkan dari kegiatan rumah tangga berupa sisa makanan, sayuran, kulit buah, bungkus makan dari daun-daunan. Sedangkan sampah anorganik adalah sampah yang tidak bisa membusuk. Menurut Marliani (2014) yang dimaksud dengan sampah anorganik ialah "sampah yang dihasilkan dari bahan-bahan non hayati baik berupa produk sintetik maupun hasil prosses teknology pengelolahan bahan tambang atau sumber daya alam dan tidak dapat diuraikan oleh alam". Limbah rumah tangga berupa barang yang terbuat dari plastik, kayu, kaca semuanya tidak mudah busuk. Plastik yang dibakar akan menimbulkan bau tidak sedap dan akan mengganggu polusi udara. Oleh karena itu, kondisi penanganan sampah rumah tangga yang masih tradisional maupun masih bersifat turun temurun memerlukan upaya peningkatan pola pikir dan kemampuan pengelolaan sampah. Salah satu dari banyak cara mengelola sampah yaitu pemanfaatan sampah untuk fungsi lain. Oleh karena itu pelatihan ini sekaligus untuk peningkatan pemahaman sampah berkaitan dengan kesehatan lingkungan dan kebermanfaatannya terhadap kehidupan keluarga. 


\section{Peserta Kegiatan dan Tim Pelaksana}

Tim abdimas dengan judul "Pemanfaatan Limbah Plastik dengan Metode Daur Ulang" beranggotakan 5 orang dosen Fakultas Keguruan dan IImu pendidikan Universitas Terbuka yang berdinas di UPBJJ-UT Yogyakarta. Peserta program abdimas pelatihan ini adalah warga ibu rumah tangga di Dusun Mrisen yang sebagian besar memiliki mata pencaharian sebagai buruh dan petani.

Lokasi dusun Mrisen berada di wilayah Kelurahan Sardonoharjo, Kecamatan Ngaglik, Kabupaten Sleman Propinsi DIY. Di sebelah utara berbatasan dengan Dusun Kembangan, sebelah Barat berbatasan dengan Dusun Wonosobo, sebelah Timur berbatasan dengan Dusun Turirejo, dan di sebelah Selatan berbatasan dengan Dusun Baturan Mriungan. Dusun Mrisen memiliki luas $85 \mathrm{Ha}$, yang terdiri dari luas pekarangan $12 \mathrm{Ha}$, sedangkan luas sawah $63 \mathrm{Ha}$. Jumlah penduduk Dusun Mrisen adalah 453 kepala keluarga. Yang tergabung dalam 5 RT. Tingkat pendidikan warga dusun Mrisen pada umumnya adalah berpendidikan SLTA.

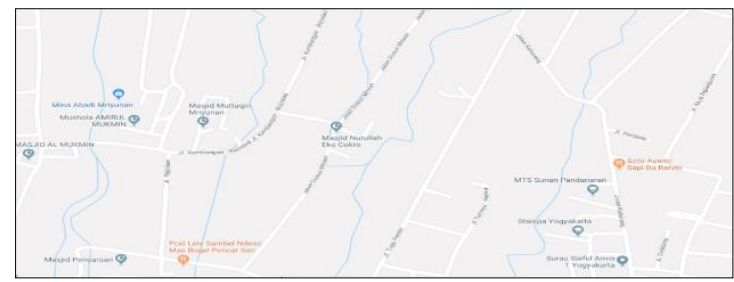

Gambar 3: Peta lokasi abdimas

Tim pelaksana pelatihan adalah 5 dosen FKIP UT UPBJJ-UT Yogyakarta telah berpengalaman dalam melakukan abdimas peningkatan kebersihan lingkungan sekolah di SMPN 2 Gamping Sleman dengan konsep penataan taman, pengelolaan sampah dan komposasi sampah. Tim juga pernah melakukan kegiatan abdimas dengan judul "Pendidikan kesehatan lingkungan melalui pengelolaan sampah rumah tangga terpadu di dusun Trini, tahun anggaran 2017. Satu dosen ahli didalam mengelola sampah anorganik dengan teknik Re-use yaitu menggunakan lagi barang yang sudah tidak dipakai seperti plastik, kertas untuk dijadikan barang baru. Masing masing anggota tim abdimas memiliki keterampilan berkreasi membuat barang dari limbah plastik menjadi barang lain yang berfungsi lain dari fungsi aslinya. Semua anggota tim juga memiliki wasasan kebersihan lingkungan sehingga konsep pengelolaan sampah yang dikaitkan dengan pendidikan kebersihan lingkungan sangat tepat dikombinasikan Alur pelatihan:

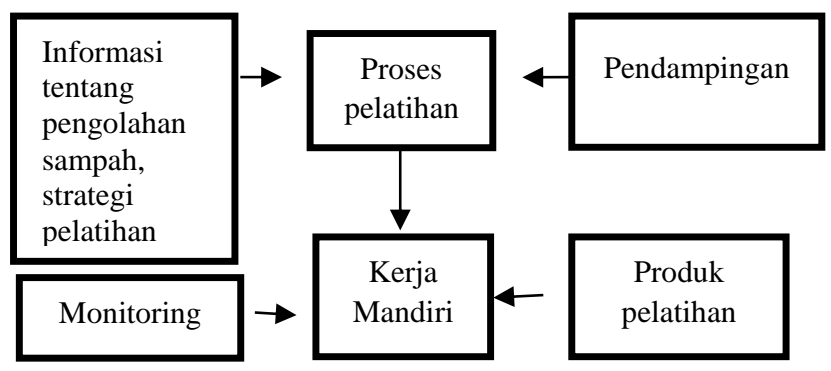

Gambar 4: Alur Pelatihan 


\section{Hasil Kegiatan}

Produk yang dihasilkan melalui pelatihan ini adalah:

1) Sower, tempat pensil dan tempat lilin. Pelatihan pembuatan sower, tempat pensil dan tempat lilin dilaksanakan pada tanggal 22 Juli 2018. Bahan dan alat yang digunakan meliputi : botol aqua bekas, solder, cuter, gunting, lem tembak, pita-pita untuk hia

2) Celengan bentuk kura-kura dan gelas cantik. Pelatihan pembuatan celengan bentuk kura-kura dan gelas cantik dilaksanakan pada tanggal 29 Juli 2018. Bahan dan alat yang digunakan meliputi : botol aqua bekas, cuter, gunting, lem tembak, pita-pita untuk hiasan, kartun, spidol, kuas, dan cat.

3) Tempat assesoris dan tempat pensil rit dan kancing. Pelatihan pembuatan tempat assesoris dan tempat pensil rit dan kancing dilaksanakan pada tanggal 29 Juli 2018. Bahan dan alat yang diperlukan meliputi botol aqua bekas, cuter, gunting, lem tembak, pita-pita untuk hiasan, kartun, spidol, kuas, rit, kancing dan cat

4) Tempat sikat gigi unik dan hiasan buah apel. Pelatihan pembuatan tempat sikat gigi unik dan hiasan buah apel dilaksanakan pada tanggal 29 Juli 2018. Bahan dan alat yang digunakan meliputi botol aqua bekas, cuter, gunting, lem tembak, pita-pita untuk hiasan, kuas, dan cat

9) Vas bunga dan tempat sovenir

Pelatihan pembuatan vas bunga dan tempat sovenir dilaksanakan pada tanggal 29 Juli 2018. Bahan dan alat yang digunakan meliputi botol aqua bekas, cuter, gunting, lem tembak, pita-pita untuk hiasan, kartun, spidol, kuas, dan cat Toples mini lebaran

10) Pelatihan pembuatan toples mini lebaran dilaksanakan pada tanggal 29 Juli 2018. Bahan dan alat yang digunakan meliputi botol aqua bekas, cuter, gunting, lem tembak, pita-pita untuk hiasan, kartun, spidol, kuas, kertas kado bekas dan cat

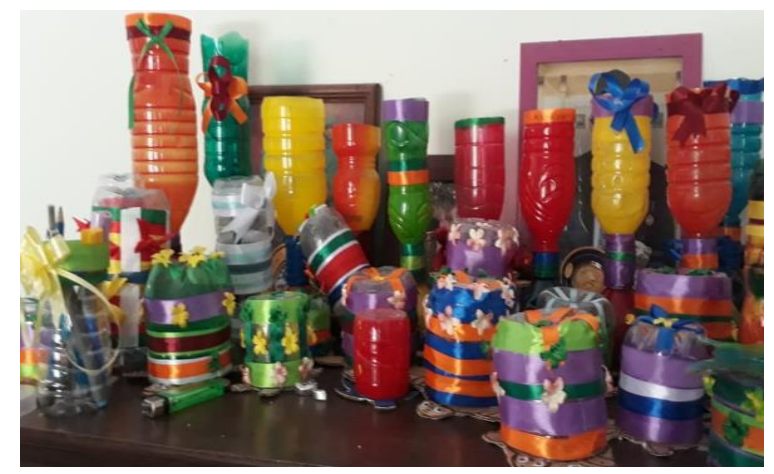

Gambar 5: Hasil Pelatihan 


\section{KESIMPULAN}

Kegiatan pelatihan pemanfaatan limbah botol plastik untuk dibuat menjadi barang lain yang bermanfaat telah berlangsung dengan baik sesuai dengan tujuan pelatihan. Pelatihan melalui salah satu cara penanganan sampah dengan sistem daur ulang dapat menambah pengetahuan dan kreativitas pemanfaatan sampah untuk barang lain yang berguna dan sekaligus dapat memberikan sosialisasi kebersihan lingkungan dan memberikan pendidikan lingkungan keluarga dan masyarakat yang memiliki lingkungan yang bersih. Pelatihan ini sifatnya hanya memberikan inisiasi pada peserta untuk berkreasi memanfaatkan limbah menjadi barang lain yang berguna atau mengubah bentuk menjadi barang yang bermanfaat. Pelatihan pemanfaatan botol plastik merupakan contoh kreatifitas yang selanjutnya dapat mendorong ibu rumah tangga lebih berkreasi memanfaatkan limbah bukan hanya dari limbah botol plastik.

\section{DAFTAR PUSTAKA}

Chaesfa, Y. \& Pandjaitan, N.E. (2013 ) Persepsi perempuan terhadap lingkungan hidup dan partisipasinya dalam pengelolaan sampah rumahtangga (kasus sebuah kampung di desa babakan, kecamatan dramaga, kabupaten bogor, provinsi jawa barat). Sodality :

Jurnal Sosiologi Pedesaan ISSN : 2302 - 7517, Vol. 01, No. 02. Agustus 2013, hlm: $165-181$

Marliani, N. (2014). Pemanfaatan limbah rumah tangga (sampah anorganik) sebagai bentuk implementasi dari pendidikan lingkungan hidup. Jurnal Formatif 4(2): 124-132, 2014 ISSN: 2088- $351 X$

Sidarto, (2010). Analisis usaha proses pengeololaan sampah rumah tangga dengan pendekatan cost and benefit rasio guna menunjang kebersihan lingkungan. Jurnal Teknologi, Volume 3, Nomor 2, Desember2010 161-168

. Kamus Besar Bahasa Indonesia, versi online di, https://www.kbbi.web.id diakses

tanggal 25 Maret 2018 